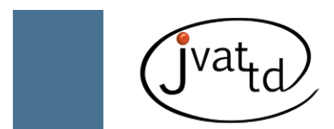

\title{
Chagas' disease and Duffy antigen/receptor for chemokine (DARC): a mini-review
}

Oliveira AP (1), Mattos LC (2), Cavasini CE (3)

(1) Masters Program in Health Sciences, São José do Rio Preto School of Medicine (FAMERP), São José do Rio Preto, São Paulo State, Brazil; (2) Laboratory of Immunogenetics, Department of Molecular Biology, São José do Rio Preto School of Medicine (FAMERP), São José do Rio Preto, São Paulo State, Brazil; (3) Center for Investigation of Microorganisms, Department of Dermatologic, Infectious and Parasitic Diseases, São José do Rio Preto School of Medicine (FAMERP), São José do Rio Preto, São Paulo State, Brazil.

\begin{abstract}
Duffy gene (FY) codifies the transmembrane glycoprotein Duffy (gp-Fy) of 35 to $43 \mathrm{kDa}$ which is moderately immunogenic. This glycoprotein is polymorphic, and constitutes the antigens of the Duffy histo-blood system which were designated receptors for chemokines and denominated DARC (Duffy antigen/receptor for chemokine). This receptor has an important role in the regulation of chemokine levels in the circulation, as it binds and adsorbs them on the surface of red cells as a reservoir. It plays a "sink" role, which can contribute to homeostasis by removing inflammatory chemokines from circulation as well as maintaining them in plasmatic levels. Chronic Chagas' cardiopathy (CCC) is the most frequent form of the disease. It is an inflammatory disease, in which infiltrated inflammatory cells play an important role in the development and progress of the infection. High chemokine levels in the plasma have been associated with the disease severity in patients with heart failure. In this context, the profile of DARC expression could play an important function as a receptor for chemokines in Chagas' disease, in patients with CCC, as it can modulate damage from this inflammatory disease.
\end{abstract}

Key words: DARC antigen, Duffy blood-group system, Chagas' disease, Chagas' cardiomyopathy.

\section{INTRODUCTION}

The Duffy gene $(F Y)$ codifies the moderately immunogenic transmembrane glycoprotein Duffy (gp-Fy) of 35 to $43 \mathrm{kDa}$ (1). This glycoprotein is polymorphic, and constitutes the antigens of the Duffy histo-blood system, which are codified by $F Y A$ and $F Y B$ alleles of the $F Y$ gene playing a codominant role. The FYA and FYB alleles differ due to substitution of the base $G$ by another $A$ in the 125 nucleotide, which develops a common polymorphism in the Caucasian population. This single nucleotide polymorphism (SNP) results in the substitution of amino acid glycine by asparagine in position 42 (2).

Although this polymorphism originates distinct glycoproteins called Fya and Fyb antigens, both have moderate immunogenicity.
They can be identified with the use of antiFya and anti-Fyb anti-sera, allowing the characterization of four erythrocyte phenotypes: Fy $(a+b-), F y(a-b+), F y(a+b+)$ and Fy $(a-b-)(3$, 4). Negative phenotype Duffy $[\mathrm{Fy}(\mathrm{a}-\mathrm{b}-)]$ is the result of a variant $F Y B$ allele (FYB-33), which presents a single point mutation where there is a $\mathrm{T}$ to $\mathrm{C}$ substitution in nucleotide $-33(-33 \mathrm{~T}>\mathrm{C})$, also known as the GATA-BOX, located in the promoter region of the $F Y$ gene $(5,6)$.

The differential distribution of DARC antigenic determinant between ethnic groups is a characteristic of this histo-blood system. As an example, FYA is prevalent in European, Chinese, Japanese, and Malaysian populations, but rarely in African population. And on the other hand, in Caucasians, FYB is widely found compared to Asian and African populations $(7,8)$. Homozygote 
individuals for allele FYB-33 (DARC negative) are common in African population, but rare in other ethnic groups (9). In Brazil, some studies on intra-ethnic genetic diversity in five geographic regions have shown some variations in the origin and ethnic composition of three subgroups (European, African, and mixed descendants) (10). Therefore, FY allele frequencies from distinct ethic groups are of great importance for phenotype and genetic composition distribution (11-15).

The Duffy antigen is expressed in erythrocytes, Purkinje cells of the cerebellum, and epithelial cells of the kidneys and lungs (1, 16-20). Erythrocytes with gp-Fy absence do not manifest alterations, therefore individuals with phenotype Fy (a-b-), who do not present antigen Duffy in their erythrocytes, are seemingly normal (21). The Duffy antigen was identified as a malaria parasite receptor, as individuals who do not express that protein in erythrocytes cannot be invaded by Plasmodium knowlesi or Plasmodium vivax (22, 23). Several studies in Brazil have demonstrated the association between the Duffy antigen and malaria by $P$. vivax; the first was by Colauto et al. (24). However, recent studies have verified infection by $P$. vivax in Fy $(\mathrm{a}-\mathrm{b}-)$ individuals from Brazil and Eastern Africa (25-28). Genetic mechanisms for the Duffy-negative phenotype in erythrocytes have preserved its expression in the endothelium determining an important role in inflammation physiopathology $(16,19)$.

Antigens of the Duffy blood system were designated chemokine receptors and denominated Duffy antigen/receptor for chemokine (DARC), as a result of experiments performed in Duffy positive individuals, who absorbed interleukin-8 (CXCL8/IL-8) on the erythrocyte surface $(1,29$ 32).

Chemokines are small cytokines of 8 to $10 \mathrm{kDa}$ that directly induce cell movement through the organism or induce specific functions in activated cells $(33,34)$. They are classified in subfamilies according to the number and location of the amino-terminal cysteine residues. Of these, two main subfamilies are highlighted: CC, in which the cysteine residues are adjacent, and CXC, in which these residues are separated by an amino acid $(35,36)$.

These chemokines can also be divided into inflammatory and homeostatic proteins, based on the conditions and production site (35-39).
Inflammatory (or induced) chemokines, such as CXCL8/IL-8, CCL5/RANTES, CCL11/eotaxin, CCL4/MIP-1 CCL2/MCP-1, and CXCL10/IP10 are produced by several cells in response to inflammatory stimulus. They work in recruiting cells such as monocytes, granulocytes and $\mathrm{T}$ cells (effector) to inflammation sites. While homeostatic (or constitutive) chemokines are expressed constitutively, and they can be involved in both lymphoid cell organization and basal leucocyte traffic $(36,40)$.

IL-8 is involved in the monocyte and neutrophil recruitment and activation process for sites of acute inflammatory response. It presents certain longevity in these sites, being produced at the beginning of inflammatory response and is active for a long period of time; days and weeks. Several studies have been performed on IL-8 and cardiovascular diseases, some identified this chemokine in vascular injury sites, while others demonstrated that it plays a role in several phases of atherosclerosis, as either a marker or a potential therapeutic target (41). Experiments carried out by Kim et al. (42) have shown IL-8 as having considerable relevance in the pathogenesis of the hypertension. Simonini et al. (43) evaluated its participation in the angiogenic activity of the atherosclerosis. They concluded that IL-8 is an important angiogenesis mediator. Other authors have demonstrated that its neutralization significantly reduces the degree of necrosis in an animal model of myocardial ischemiareperfusion injury $(41,44)$.

Unlike other chemokine receptors, DARC is a promiscuous receptor, because it interacts with both CC and CXC classes with high affinity, while most chemokine receptors link themselves to just one of the classes $(31,45-48)$. The Duffy antigen is a receptor for inflammatory chemokines. Experiments have demonstrated DARC has an affinity with the following 16 chemokines: CXCL1, CXCL2, CXCL3, CXCL4, CXCL5, CXCL6, CXCL7, CXCL8, CXCL11, CCL2, CCL5, CCL7, CCL11, CCL13, CCL14, and CCL17 (49, 50). Immunohistochemical studies have demonstrated DARC expression on the surface of venule and small vein endothelial cells, considered important sites for recruiting leukocytes to inflammation areas, induced by chemokines and facilitating their movement through the endothelium of different tissues (16, $51,52)$. Studies suggest DARC contribution in 
chemokine transcytosis from the intravascular to the extravascular space, favoring the migration of leukocytes involved in inflammation $(50,53)$. DARC plays an important role in the regulation of circulation chemokine levels, as it binds to and adsorbs them on the surface of red cells, as a chemokine reservoir performing a "sink" role $(29,50)$. Therefore, DARC can collaborate with homeostasis in the removal of inflammatory chemokines in the circulation, thus avoiding the loss of these inflammatory mediators for organs and distant tissues, as well as maintaining them in plasma levels, due to subsequent liberation from the erythrocyte surface $(50,54)$. However, the theory that DARC plays a "sink" function has been questioned. Some authors have demonstrated that there is no chemokine intracellular variation associated to DARC (55). Thus, further investigations are needed to better understand this role of DARC.

DARC is involved in several "classic" chemokine receptor diseases such as giant cell arteritis, renal diseases and transplantations, as well as during acute transplant rejection $(56,57-$ $60)$. Susceptibility to asthma was correlated with the absence of DARC expression in red cells from certain Afro-descendant populations (61). A recent study showed that the absence of DARC in erythrocytes resulted in a $40 \%$ increase in the risk of acquiring HIV; however, these individuals presented a short-term progression of the disease $(55,62)$. Epidemiological data suggest that DARC absence in the erythrocyte has contributed to an increase in prostate cancer incidence and mortality $(46,63)$. DARC expression in cancerous lung cells may be associated with decreased tumor vascularization and a reduction in metastatic potential, as well as a decrease breast cancer cell growth, due to sequestration of angiogenic chemokines and inhibition of tumor vascularization $(64,65)$.

\section{DARC AND CHAGAS' DISEASE}

Chagas' disease was described by the great scientist Carlos Chagas in 1909. It is a parasitic disease that occurs particularly in America. Its etiological agent is the flagellated protozoan Trypanosoma cruzi belonging to the phylum Protozoa, order Kinetoplastida, family Trypanosomatidae and the gender Trypanosoma $(66,67)$. The main transmission form to the human host is by insects of the order Hemiptera, family Reduviidae and genera Triatoma, Panstrongylus and Rhodnius $(68,69)$. Other transmission mechanisms such as blood transfusions and congenital transmission have also been reported in mainly urban areas and non-endemic countries (70). Nearly 15 to 16 million people are infected by T. cruzi in Latin America (71).

Inflammatory cytokines play a central role in infection by T. cruzi. The acute phase of Chagas' disease is characterized by an exacerbated production of inflammatory cytokines, including IL-12, TNF- $\alpha$, and IFN- $\gamma$, and chemokines such as CCL2, CCL3, CCL4, CCL5, and CXCL10 $(72,73)$. CCL5 and CCL2, which bind to the Duffy antigen, have been singled out from these inflammatory mediators.

After the acute phase, most individuals are asymptomatic as they present the indeterminate form of Chagas' disease, while between 30 to $40 \%$ of parasitized individuals can develop heart, digestive, or mixed problems. The most frequent form, inflammatory myocardiopathy also known as chronic chagasic cardiopathy (CCC) accounts for 20 to $30 \%$ of individuals (74).

CCC is an inflammatory disease, characterized by the presence of diffuse myocarditis with a remodeling process of intense myocardial fibrosis, hypertrophy, and lesion of cardiac muscular fibers $(75,76)$. Clinical data suggest that the inflammatory infiltrate plays an important role in the development and progression of Chagas' disease, as mononuclear infiltrate is associated with greater cardiomyocyte destruction and local fibrosis in CCC $(76,77)$. Development of this myocardiopathy involves three possible pathogenic mechanisms: cardiac dysautonomia, microcirculation changes, and tissue damage resulting from the inflammatory and immune responses (73).

The chronic phase of the disease also presents high inflammatory cytokine production, possibly due to longer exposure to the parasite. An increase in plasmatic TNF- $\alpha$ and IFN- $\gamma$ levels occurs; this is also observed in patients with the indeterminate form of the disease. Individuals with CCC present high TNF- $\alpha$ and CCL2 levels in the circulation in relation to those with the indeterminate form (73). It is important to point out the inflammatory chemokines whose receptor is DARC; these include CXCL8/IL-8, CCL5/ RANTES, CCL11/eotaxin, and CCL2/MCP-1. 
High chemokine concentrations in plasma have been associated with disease severity in patients with CCC, for example high levels of CCL2 and TNF- $\alpha$, the latter directly correlating with the degree of heart failure in these patients (78). Experiments carried out by Cunha-Neto et al. (79) suggest that IFN- $\gamma$ and CCL2 are related to gene expression of the cardiomyocytes involved in the pathological hypertrophy process. Moreover, the intensity of acute and chronic myocarditis in mice $(\mathrm{C} 3 \mathrm{H} / \mathrm{He})$ infected with Colombian strain was directly associated with CCL2 concentration in the heart (80).

High expression of CCR5 (receptor for CCL3, CCL4, and CCL5) was detected in leukocyte patients with chagasic cardiomyopathy. Polymorphism in the promoter region of the CCR5 gene (CCR5 $59029 \mathrm{~A} \rightarrow \mathrm{G}$ ), associated with lower CCR5 expression in leukocytes was more frequent in asymptomatic patients than those with chagasic cardiomyopathy $(78,81)$. Others studies have shown that mice lacking the CCR5 receptor present a significant reduction of cardiac inflammatory infiltrate, suggesting the importance of this receptor in lymphocyte migration and control of local parasite replication (82). It is important to emphasize that DARC presents a significant homology with receptor CCR5, and it is also a receptor for chemokine CCL5 (55).

Studies carried out by Damås et al. (83) have demonstrated the presence of CCL2 and CXCL8 in cardiomyocytes. This suggests the important role these cells play in the inflammatory process, either by chemokine production, or by expressing their receptor. High chemokine expression and corresponding receptors in the myocardium and circulating leukocytes suggests a relevant function for these mediators in various forms of myocardial failure (84). Experiments carried out with patients who presented with CCC revealed high chemokine expression in heart tissue. Other data suggest that local production of these inflammatory mediators can perform a highly important function in the heart damage observed in CCC (85).

\section{CONCLUDING REMARKS}

Although investigated in several studies, the actual role of chemokines in myocardium disease is not completely explained. In this context, the profile of DARC expression plays an important role as a chemokine receptor in Chagas' disease patients with CCC. It can modulate damage by this inflammatory disease. However, many aspects of Duffy antigen biology should be considered when determining their effective functions, because despite all the knowledge on the relationship between DARC structure/function and tissue location, its effective role still remains uncertain in normal and damaged physiology.

\section{ACKNOWLEDGEMENTS}

Weare grateful to the Microorganism Investigation Center of FAMERP for lending us its facilities and to The National Council for Scientific and Technological Development (CNPq) for their financial support and for Amanda Priscila de Oliveira's scholarship.

\section{COPYRIGHT \\ (C) CEVAP 2011}

\section{SUBMISSION STATUS}

Received: April 6, 2011.

Accepted: June 2, 2011.

Abstract published online: June 7, 2011.

Full paper published online: August 31, 2011.

\section{CONFLICTS OF INTEREST}

There are no conflicts of interest.

\section{FINANCIAL SOURCE}

The National Council for Scientific and Technological Development (CNPq) provided the financial grant (process number 135436/2009-5).

\section{CORRESPONDENCE TO}

CARLOS EUGENIO CAVASINI, Centro de Investigação de Microorganismos, Faculdade de Medicina de São José do Rio Preto, Av. Brigadeiro Faria Lima, 5416, São José do Rio Preto, SP, 15090-000, Brazil. Tel: +55 173201 5736. Email: cecavasini@yahoo.com.br.

\section{REFERENCES}

1. Hadley TJ, Peiper SC. From malaria to chemokine receptor: the emerging physiologic role of the Duffy blood group antigen. Blood. 1997;89(9):3077-91.

2. Chaudhuri A, Polyakova J, Zbrzezna V, Williams K, Gulati S, Pogo AO. Cloning of glycoprotein D cDNA, which encodes the major subunit of the Duffy blood group system and the receptor for the Plasmodium vivax malaria parasite. Proc Natl Acad Sci U S A 1993;90(22):10793-7. 
3. Race RR, Sanger R. Blood groups in man. $6^{\text {rd }}$ ed. Oxford: Blackwell Scientific Publications; 1975.

4. Mollison PL, Engelfriet CP, Contreras M. Blood transfusion in clinical medicine. $10^{\text {rd }}$ ed. Oxford: Blackwell Science; 1997.

5. Tournamille C, Colin Y, Cartron JP, Le Van Kim C. Disruption of a GATA motif in the Duffy gene promoter abolishes erythroid gene expression in Duffy-negative individuals. Nat Genet. 1995;10(2):224-8.

6. Iwamoto $\mathrm{S}$, $\mathrm{Li} \mathrm{J}$, Omi $\mathrm{T}$, Ikemoto $\mathrm{S}$, Kajii $\mathrm{E}$. Identification of a novel exon and spliced form of Duffy mRNA that is the predominant transcript in both erythroid and postcapillary venule endothelium. Blood. 1996;87(1):378-85.

7. Lewis Jr GE, Miller LH, Ibrahim L, Wong PW, McGinniss M, Ooi WL. Duffy phenotypes in Malaysian populations: correction of previous unusual findings. Trans R Soc Trop Med Hyg 1988;82(3):509-10.

8. Pogo AO, Chaudhuri A. The Duffy protein: a malarial and chemokine receptor. Semin Hematol. 2000;37(2):122-9.

9. Mourant A, Kopec A, Domaniewska-Sobczak K. The distribution of the human blood groups and other polymorphisms. $2^{\text {rd }}$ ed. London: Oxford University Press; 1976.

10. Salzano FM, Bortolini MC. Normal genetic variation at the protein, glycoconjugate and DNA levels. In: Mascie-Taylor NCG, editor. The evolution and genetics of Latin American population. $1^{\text {st }}$ ed. Cambridge: Cambridge University Press; 2002. p. 255.

11. Bortolini C, Weimer TA, Franco MH, Salzano FM, Layrisse Z, Schneider $\mathrm{H}$ et al. Genetic studies in three South American black populations. Gene Geogr. 1992;6(1-2):1-16.

12. Castilho L, Rios M, Pellegrino J Jr, Saad ST, Costa FF, Reid MR. A novel Fy allele in Brazilians. Vox Sang. 2004;87(3):190-5.

13. Dornelles CL, Callegari-Jacques SM, Robinson WM, Weimer TA, Franco MH, Hickmann AC, et al. Genetics, surnames, grandparents' nationalities, and ethnic admixture in southern Brazil - do the patterns of variation coincide? Gen Mol Biol. 1999;22(2):151-61.

14. Parasol N, Cohen N, Zemishlany Z, Lerer B, Kosower NS. Duffy antigen/receptor for chemokines (DARC): genotypes in Ashkenazi and bon-Ashkenazi Jews in Israel. Hum Biol. 2001;73(2):307-13.

15. Estalote AC, Proto-Siqueira R, Silva WA Jr, Zago MA, Palatnik M. The mutation G298A $\rightarrow$ Ala100Thr on the coding sequence of the Duffy antigen/chemokine receptor gene in non-caucasian Brazilians. Gent Mol Res. 2005;4(2):166-73.

16. Hadley TJ, Lu ZH, Wasniowska K, Martin AW, Peiper SC, Hesselgesser J, et al. Postcapillary venule endothelial cells in kidney express a multispecific chemokine receptor that is structurally and functionally identical to the erythroid isoform, which is the Duffy blood group antigen. J Clin Invest. 1994;9(3)4:985-91.

17. Girard JP, Baekkevold ES, Yamanaka T, Haraldsen G, Brandtzaeg P, Amalric F. Heterogeneity of endothelial cells: the specialized phenotype of human high endothelial venules characterized by suppression subtractive hybridization. Am J Pathol. 1999;155(6):2043-55.

18. Horuk R, Martin AW, Wang Z, Schweitzer L, Gerassimides A, Guo H, et al. Expression of chemokine receptors by subsets of neurons in the central nervous system. J Immunol. 1997;158(6):2882-90.

19. Peiper SC, Wang ZX, Neote K, Martin AW, Showell HJ, Conklyn MJ, et al. The Duffy antigen/receptor for chemokines (DARC) is expressed in endothelial cells of Duffy negative individuals who lack the erythrocyte receptor. J Exp Med. 1995;181(4):1311-7.

20. Chaudhuri A, Nielsen S, Elkjaer ML, Zbrzezna V, Fang F, Pogo AO. Detection of Duffy antigen in the plasma membranes and caveolae of vascular endothelial and epithelial cells of nonerythroid organs. Blood. 1997;89(2):701-12.

21. Mallinson G, Soo KS, Schall TJ, Pisacka M, Anstee DJ. Mutations in the erythrocyte chemokine receptor (Duffy) gene: the molecular basis of the Fya/Fyb antigens and identification of a deletion in the Duffy gene of an apparently healthy individual with the Fy(a-b-) phenotype. Br J Haematol. 1995;90(4):823-9.

22. Miller LH, Mason SJ, Dvorak JA, McGinniss $\mathrm{MH}$, Rothman IK. Erythrocyte receptors for (Plasmodium knowlesi) malaria: Duffy blood group determinants. Science. 1975;189(4202):561-3.

23. Miller LH, Mason SJ, Clyde DF, McGinniss MH. The resistance factor to Plasmodium vivax in blacks. The Duffy-blood-group genotype, FyFy. N Engl J Med. 1976;295(6):302-4.

24. Colauto EM, Barraviera B, Meira DA, Matsubara LS, Pellegrino-Junior J, Machado PE, et al. Malária no município de Humaitá, Estado do Amazonas. XII - Frequência de fatores de resistência eritrocitária na população geral e em doentes: hemoglobina $\mathrm{S}$ e sistem sanguíneo Duffy. Rev Inst Med Trop São Paulo. 1981;23(supl.5):72-8.

25. Ryan JR, Stoute JA, Amon J, Dunton RF, Mtalib R, Koros J, et al. Evidence for transmission of Plasmodium vivax among a Duffy antigen negative population in Western Kenya. Am J Trop Med Hyg. 2006;75(4):57581.

26. Rosenberg R. Plasmodium vivax in Africa: hidden in plain sight? Trends Parasitol 2007;23(5):193-6.

27. Cavasini CE, de Mattos LC, Couto AA, Couto VS, Gollino Y, Moretti LJ, et al. Duffy blood group gene polymorphisms among malaria vivax patients in four areas of the Brazilian Amazon region. Malar J. 2007;6:167.

28. Culleton RL, Mita T, Ndounga M, Unger H, Cravo PV, Paganotti GM, et al. Failure to detect Plasmodium vivax in West and Central Africa by PCR species typing. Malar J. 2008;7:174.

29. Darbonne WC, Rice GC, Mohler MA, Apple T, Hébert CA, Valente AJ, et al. Red blood cells are a sink for interleukin 8, a leukocyte chemotaxin. J Clin Invest 1991;88(4):1362-9.

30. Neote K, Darbonne W, Ogez J, Horuk R, Schall TJ. Identification of a promiscuous inflammatory peptide receptor on the surface of red blood cells. J Biol Chem. 1993;268(17):12247-9. 
31. Horuk R, Chitnis CE, Darbonne WC, Colby TJ, Rybicki A, Hadley TJ, et al. A receptor for the malarial parasite Plasmodium vivax: the erythrocyte chemokine receptor. Science. 1993;261(5125):1182-4.

32. Horuk R, Wang ZX, Peiper SC, Hesselgesser J. Identification and characterization of a promiscuous chemokine-binding proteininahuman erythroleukemic cell line. J Biol Chem 1994;269:17730-3.

33. Luster AD. Chemokines-chemotactic cytokines that mediate inflammation. N Engl J Med.1998;338(7):43645.

34. Mantovani A. The chemokine system: redundancy for robust outputs. Immunol Today. 1999;20(6):254-7.

35. Cyster JG. Chemokines and cell migration in secondary lymphoid organs. Science. 1999;286(5447):2098-102.

36. Sallusto F, Mackay CR, Lanzavecchia A. The role of chemokine receptors in primary, effector, and memory immune responses. Annu Rev Immunol. 2000;18:593620

37. Loetscher P, Moser B, Baggiolini M. Chemokines and their receptors in lymphocyte traffic and HIV infection. Adv Immunol. 2000;74:127-80.

38. von Andrian UH, Mackay CR. T-cell function and migration. Two sides of the same coin. N Engl J Med. 2000;343(14):1020-34.

39. Campbell JJ, Butcher EC. Chemokines in tissuespecific and microenvironment-specific lymphocyte homing. Curr Opin Immunol. 2000;12(3):336-41.

40. Moser B, Loetscher P. Lymphocyte traffic control by chemokines. Nat Immunol.2001;2(2):123-8.

41. Apostolakis S, Vogiatzi K, Amanatidou V, Spandidos DA. Interleukin 8 and cardiovascular disease. Cardiovasc Res. 2009;84(3):353-60.

42. Kim HY, Kang YJ, Song IH, Choi HC, Kim HS. Upregulation of interleukin-8/CXCL8 in vascular smooth muscle cells from spontaneously hypertensive rats. Hypertens Res. 2008;31(3):515-23.

43. Simonini A, Moscucci M, Muller DW, Bates ER, Pagani FD, Burdick MD, et al. IL- 8 is an angiogenic factor in human coronary atherectomy tissue. Circulation. 2000;101(13):1519-26.

44. Boyle EM Jr, Kovacich JC, Hèbert CA, Canty TG Jr, Chi E, Morgan EN, et al. Inhibition of interleukin-8 blocks myocardial ischemia-reperfusion injury. J Thorac Cardiovasc Surg. 1998;116(1):114-21.

45. Szabo MC, Soo KS, Zlotnik A, Schall TJ. Chemokine class differences in binding to the Duffy antigenerythrocyte chemokine receptor. J Biol Chem. 1995;270(43):25348-51.

46. Lentsch AB. The Duffy antigen/receptor for chemokines (DARC) and prostate cancer. A role as clear as black and white? FASEB J. 2002;16(9):1093-5.

47. Chaudhuri A, Zbrzezna V, Polyakova J, Pogo AO, Hesselgesser J, Horuk R. Expression of the Duffy antigen in K562 cells. Evidence that it is the human erythrocyte chemokine receptor. J Biol Chem. 1994;269(11):7835-8.

48. Lu ZH, Wang ZX, Horuk R, Hesselgesser J, Lou YC, Hadley TJ, et al. The promiscuous chemokine binding profile of the Duffy antigen/receptor for chemokines is primarily localized to sequences in the amino- terminal domain. J Biol Chem.1995;270(4):26239-45.

49. Gardner L, Patterson AM, Ashton BA, Stone MA, Middleton J. The human Duffy antigen binds selected inflammatory but not homeostatic chemokines. Biochem Biophys Res Commun. 2004;321(2):306-12.

50. de Brevern AG, Autin L, Colin Y, Bertrand O, Etchebest C. In silico studies on DARC. Infect Disord Drug Targets. 2009;9(3):289-303.

51. Rot A. Contribution of Duffy antigen to chemokine function. Cytokine Growth Factor Rev. 2005;16(6):68794.

52. Lee JS, Frevert CW, Thorning DR, Segerer S, Alpers CE, Cartron JP, et al. Enhanced expression of Duffy antigen in the lungs during suppurative pneumonia. J Histochem Cytochem. 2003;51(2):159-66.

53. Pruenster M, Mudde L, Bombosi P, Dimitrova S, Zsak $\mathrm{M}$, Middleton J, et al. The Duffy antigen receptor for chemokines transports chemokines and supports their promigratory activity. Nat Immunol. 2009;10(1):1018.

54. Pruenster $\mathrm{M}$, Rot A. Throwing light on DARC. Biochem Soc Trans 2006;34(Pt 6):1005-8.

55. Horne K, Woolley IJ. Shedding light on DARC: the role of the Duffy antigen/receptor for chemokines in inflammation, infection and malignancy. Inflamm Res. 2009;58(8):431-5.

56. Brühl H, Vielhauer V, Weiss M, Mack M, Schlöndorff D, Segerer S. Expression of DARC, CXCR3 and CCR5 in giant cell arteritis. Rheumatology (Oxford). 2005;44(3):309-13.

57. Liu XH, Hadley TJ, Xu L, Peiper SC, Ray PE. Up-regulation of Duffy antigen receptor expression in children with renal disease. Kidney Int.1999;55(4):1491-500.

58. Segerer S, Regele H, MacK M, Kain R, Cartron JP, Colin $\mathrm{Y}$, et al. The Duffy antigen receptor for chemokines is up-regulated during acute renal transplant rejection and crescentic glomerulonephritis. Kidney Int. 2000;58(4):1546-56.

59. Segerer S, Cui Y, Eitner F, Goodpaster T, Hudkins KL, Mack M, et al. Expression of chemokines and chemokine receptors during human renal transplant rejection. Am J Kidney Dis. 2001;37(3):518-31.

60. Segerer S, Böhmig GA, Exner M, Colin Y, Cartron JP, Kerjaschki D, et al. When renal allografts turn DARC. Transplantation. 2003;75(7):1030-4.

61. Vergara C, Tsai YJ, Grant AV, Rafaels N, Gao L, Hand, T, et al. Gene encoding Duffy antigen/receptor for chemokines is associated with asthma and $\operatorname{IgE}$ in three populations. Am J Respir Crit Care Med. 2008;178(10):1017-22.

62. He W, Neil S, Kulkarni H, Wright E, Agan BK, Marconi $\mathrm{VC}$, et al. Duffy antigen receptor for chemokines mediates trans-infection of HIV-1 from red blood cells to target cells and affects HIV-AIDS susceptibility. Cell Host Microbe. 2008;4(1):52-62.

63. Shen H, Schuster R, Stringer KF, Waltz SE, Lentsch AB. The Duffy antigen/receptor for chemokines (DARC) regulates prostate tumor growth. FASEB J. 2006;20(1):59-64.

64. Addison CL, Belperio JA, Burdick MD, Strieter RM. 
Overexpression of the duffy antigen receptor for chemokines (DARC) by NSCLC tumor cells results in increased tumor necrosis. BMC Cancer. 2004;4:14-28.

65. Wang J, Ou ZL, Hou YF, Luo JM, Shen ZZ, Ding J, et al. Enhanced expression of Duffy antigen receptor for chemokines by breast cancer cells attenuates growth and metastasis potential. Oncogene. 2006;25(54):720111.

66. Tibayrenc M, Ward P, Moya A, Ayala F. Natural populations of Trypanosoma cruzi, the agent of Chagas disease, have a complex multiclonal structure. Proc Natl Acad Sci U S A. 1986; 83(1):115-9.

67. Ramirez LE, Machado MI, Maywald PG, Matos A, Chiari E, Silva EL. First evidence of Trypanosoma rangeli in the southeast of Brazil, an endemic region to Chagas disease. Rev Soc Bras Med Trop. 1998; 31(1):99-102.

68. Lent H, Wygodzinsky P. Revision of the Triatominae (Hemiptera, Reduviidae), and their significance as vectors of Chagas disease. Bull Am Mus Nat Hist. 1979; 163(3):125-520.

69. Carcavallo RU, Girón IG, Jurberg J, Lent H. Atlas dos vetores da doença de Chagas nas Américas. Vol. II. $1^{a}$ ed. Rio de Janeiro: Editora Fiocruz; 1998.

70. Rassi A Jr, Rassi A, Marin-Neto JA. Chagas disease. Lancet. 2010;375:1388-402.

71. Coura JR. Chagas disease: what is known and what is needed - a background article. Mem Inst Oswaldo Cruz. 2007;102(1):113-22.

72. Bilate AM, Cunha-Neto E. Chagas disease cardiomyopathy: current concepts of an old disease. Rev Inst Med Trop São Paulo. 2008;50(2):67-74.

73. Cunha-Neto E, Nogueira LG, Teixeira PC, Ramasawmy $\mathrm{R}$, Drigo SA, Goldberg AC, et al. Immunological and non-immunological effects of cytokines and chemokines in the pathogenesis of chronic Chagas disease cardiomyopathy. Mem Inst Oswaldo Cruz. 2009;104(1):252-8.

74. Rassi A Jr, Rassi A, Little WC. Chagas heart disease. Clin Cardiol. 2000; 23(12):883-9.

75. Pereira Barretto AC, Mady C, Arteaga-Fernandez E, Stolf N, Lopes EA, Higuchi ML, et al. Right ventricular endomyocardial biopsy in chronic Chagas' disease. Am Heart J. 1986;111(2):307-12.

76. Higuchi ML, De Morais CF, Pereira Barreto AC, Lopes EA, StolfN, BellottiG, etal. The role of active myocarditis in the development of heart failure in chronic Chagas' disease: a study based on endomyocardial biopsies. Clin Cardiol. 1987;10(11):665-70.
77. Higuchi M de L, Gutiérrez PS, Aiello VD, Palomino S, Bocchi E, Kalil J, et al. Immunohistochemical characterization of infiltrating cells in human chronic chagasic myocarditis: comparison with myocardial rejection process. Virchows Arch A Pathol Anat Histopathol. 1993;423(3):157-60.

78. Talvani A, Rocha MO, Ribeiro AL, Correa-Oliveira $\mathrm{R}$, Teixeira MM. Chemokine receptor expression on the surface of peripheral blood mononuclear cells in Chagas disease. J Infect Dis. 2004;189(2):214-20.

79. Cunha-Neto E, Dzau VJ, Allen PD, Stamatiou D, Benvenutti L, Higuchi ML, et al. Cardiac gene expression profiling provides evidence for cytokinopathy as a molecular mechanism in Chagas' disease cardiomyopathy. Am J Pathol 2005;167(2):30513.

80. Lannes-Vieira J, Silverio JC, Pereira IR, Vinagre NF, Carvalho CM, Paiva CN, et. al. Chronic Trypanosoma cruzi-elicited cardiomyopathy: from the discovery to the proposal of rational therapeutic interventions targeting cell adhesion molecules and chemokine receptors - how to make a dream come true. Mem Inst Oswaldo Cruz. 2009;104(Suppl 1):226-35.

81. Calzada JE, Nieto A, Beraún Y, Martín J. Chemokine receptor CCR5 polymorphisms and Chagas' disease cardiomyopathy. Tissue Antigens. 2001;58(3):154-8.

82. Machado FS, Koyama NS, Carregaro V, Ferreira BR, Milanezi CM, Teixeira MM, et al. CCR5 plays a critical role in the development of myocarditis and host protection in mice infected with Trypanosoma cruzi. J Infect Dis. 2005;191(4):627-36.

83. Damås JK, Eiken HG, Oie E, Bjerkeli V, Yndestad A, Ueland T, et al. Myocardial expression of CC- and CXC-chemokines and their receptors in human endstage heart failure. Cardiovasc Res. 2000;47(4):778-87.

84. Aukrust P, Damås JK, Gullestad L, Frøland SS. Chemokines in myocardial failure - pathogenic importance and potential therapeutic targets. Clin Exp Immunol. 2001;124(3):343-5.

85. Cunha-Neto E, Teixeira PC, Fonseca SG, Bilate AM, Kalil J. Myocardial gene and protein expression profiles after autoimmune injury in Chagas' disease cardiomyopathy. Autoimmun Rev. 2011;10(3):163-5. 